\title{
Distribution of Medical Record Personnel on Medical Record and Health Information Services in the Health Centre in Serang City in 2016
}

\section{Detia Nurpelita Sari and Nanda Aula Rumana}

Health Science Faculty, Esa Unggul University, Jakarta, Indonesia

\section{Abstract}

Availability of qualified health personnel in adequate amounts is essential for healthy development in the region to achieve better health development. Related to the importance of health, distribution of medical records personnel must be done evenly so that the hospital or health providers will have medical records staff by their competence. Puskesmas (Community Health Centre) is a very important public health care facility in Indonesia. Therefore, medical records of personnel are very needed there. This

Corresponding Author: Detia Nurpelita Sari detianurpelitasari@yahoo.com

Received: 26 December 2018 Accepted: 23 February 2019 Published: 7 March 2019

Publishing services provided by Knowledge E

(c) Detia Nurpelita Sari and Nanda Aula Rumana. This article is distributed under the terms of the Creative Commons

Attribution License, which permits unrestricted use and redistribution provided that the original author and source are credited.

Selection and Peer-review under the responsibility of the $2 \mathrm{nd}$ International Meeting of Public Health 2016 Conference Committee. study aimed to determine the distribution of medical records personnel in Community health center in Serang City in $\mathbf{2 0 1 6}$ with based on four aspects namely educational background, employment status, training history and length of service. The research was conducted in Serang City Community Health Centre on June 2016. The sampling technique used saturated samples taken from a population of 63 medical records personnel. Research showed the number of medical record personnel educational background in medical records and health information was 11 people (17.4\%), medical record personnel number whose employment status of civil servants (PNS) was 48 person (76.2\%), medical records personnel who were contracted employee was 15 people (23.8\%), medical records personnel number who hada history of training in medical records was 10 people (15.9\%), Generally, medical records personnel in Community Health Center Serang had 10 years of service period. It was expected that the recruitment of new medical records personnel in Community health center in the Serang City must have an educational background in medical records and health information.

Keywords: Distribution; personnel; medical record

\section{Introduction}

Availability of qualified health personnel in adequate amounts is essential for healthy development in the region to achieve better health development. Besides the health personnel should be evenly distributed in the health service, the other important thing 
from a health information system. Based on the Decree No. 269/Menkes/Per/III/2008, the medical record is the file containing the records and documents of identity, examination, treatment, action, and other services that have given to patients (DepkesRI 2008). If we see from the importance of medical records in the health service, the hospital or health care providers must have health personnel who compete in their field.

Based on the Minister of Health Decree No. 377/Menkes/SK/III/2007 on standard of medical record and health information profession, the medical history and health information personnel is a person who has finished formal education of medical records and health information so that he/she has the competence recognized by the government and the profession (Depkes RI 2007). Puskesmas (Community Health Center) is a public health care facilities which are very important in Indonesia. The community health center is an operation unit office district/city which has a responsibility to organize health development in a working area (Depkes RI 2004). It is essential for Community health center as providers of health care to have medical records and health information personnel. By quantity, the medical records personnel in Indonesia meet existing standards under the rules of Decree No. 340/Menkes/Per/III/2010 which state that the minimal amount of medical records personnel on Community health center is 1-4 (Kemenkes RI 2010). If we see regarding quality, there are still many medical record personnel who does not has formal education background from medical records and health information. The distribution of medical record personnel in Indonesia have not been evenly distributed, so there are still many hospitals/health centers in underdeveloped regions that have not had the medical records personnel. The medical record is significant in this era because the government commits to provide universal health coverage through Law No. 40 of 2004 on National Social Security System (Navigation) and Law 24 of 2011 on Providing Social Security Agency (BPJS) that have imposed in hospitals and other medical facilities. Therefore the role of personal medical records and health information are required in accuracy codification determination and classification of diseases according to ICD-10 and ICD-9cm that will impact on the financing of health insurance. In the processing of medical records such as assembling, processing information, health information reporting must be done by a qualified medical history with education background min. Diploma of medical records and health information to can be done by the competency standards of a medical recorder and health information.

In Serang City, medical records personnel already started to be taken into account. Regarding quantity, hospitals and Community health center already have enough the medical records personnel, but it has not evenly distributed. In Community health centerCipocok there are three medical records staff who all of them do not has educational background of medical records. As mentioned, there are still many medical record 
personnel who does not has formal education background from medical records and health information. Based on preliminary observations, many medical records personnel in Puksesmas of Serang who has been included for a long time in medical record unit with no medical record background.

Medical records personnel in Community health center of Serang city studied the medical records of a self-taught because they assume that medical records can still be done by anyone, including nurses, doctors, and other health personnel. For example, in Community health center Kasemen only have three medical records staff with a nursing background. Generally, medical records personnel in Community health center in Serang are government officers and has been being employed for a long time with no medical record background. Based on these conditions, the government should make policy, to recruit more medical record personnel with medical record background. In 2014, Banten province only allocated 3 (three) for medical record personnel. The amount is minimal considering the vast area of Banten consists of 4 Cities, 4 District, 154 sub-districts, 262 villages, and 1.273 village

This research aimed to look at the distribution of medical record personnel by referring to four aspects, namely, the educational background of medical records, employment status, and training history, and length of a service period.

\section{Methods}

The research was conducted in Community health center in Serang and held in June 2016. This research was descriptive research with the quantitative approach - the sampling technique used saturated samples taken from a population of 63 medical records personnel. The data source of this research was primary data which was made of observation and interviews using a questionnaire study - analysis of data used univariate analysis.

\section{Results and Discussion}

Serang City is one of eight regencies/cities in Banten province and is the result of the expansion of the district of Serang. Serang has 16 Community health center spread in Serang area.

Table 1 showed that the medical records personnel were still not evenly distributed in Serang. The evidence from the number of medical records personnel was most numerous in Puskesam of Subdistrict Serang which had eight medical records personnel, while 
TABLE 1: The Distribution of Medical Record Personnel based on The Number of Personnel in the Year 2016.

\begin{tabular}{l|l} 
Community Health Centre & QTY \\
Curug & 3 Personnel \\
Walantaka & 3 Personnel \\
\hline Kalodran & 3 Personnel \\
Banjar Agung & 5 Personnel \\
\hline Banten Girang & 4 Personnel \\
\hline Cipocok Jaya & 3 Personnel \\
\hline Singandaru & 3 Personnel \\
\hline Serang & 8 Personnel \\
\hline Caracas & 3 Personnel \\
\hline Rau & 4 Personnel \\
Unyur & 4 Personnel \\
\hline Taktakan & 3 Personnel \\
\hline Panacur & 4 Personnel \\
\hline Kailash & 5 Personnel \\
Kasemen & 3 Personnel \\
\hline Sawah Luhur & 5 Personnel \\
\hline Total & 63 Personnel \\
\hline
\end{tabular}

the average medical records personnel in Community health center Serang was three personnel.

TABLE 2: The Distribution of Medical Record Personnel Based on medical Record Education Year 2016.

Medical Record Education
Available
Not Available
Total

\begin{tabular}{|c|c|}
\hline Qty & $\%$ \\
\hline 11 personnel & $17.4 \%$ \\
\hline 52 staff & $82.5 \%$ \\
\hline 63 personnel & $100 \%$ \\
\hline
\end{tabular}

According to table 2, it shoed that there was still a small number of medical record personnel who had an educational background in medical records and health information. The evidence from the 63 medical records personnel in Community health center Serang was only 11 people (17.4\%) who had medical record educational background and a large part of medical records personnel did not have the educational experience of medical records and health information with the number of 52 people (82.5\%).

TABLE 3: The Distribution of Medical Record Personnel Based on Employment StatusYear 2016.
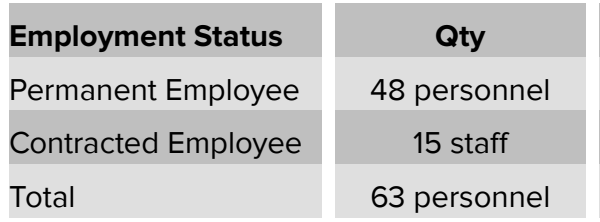

\begin{tabular}{|c|}
\hline$\%$ \\
\hline $76.2 \%$ \\
\hline $23.8 \%$ \\
\hline $100 \%$ \\
\hline
\end{tabular}


Based on Table 3, it was known that most of the medical records personnel in Community health center Serang were 48 people as permanent employee (76.2\%). The remaining of medical record personnel were contracted employee 15 (23.8\%).

TABLE 4: The Distribution of Medical Record Personnel Based on Training History Year 2016.

Training
Have been trained
Have not been trained
Total

\begin{tabular}{|c|}
\hline Qty \\
\hline Ten personnel \\
\hline 53 personnel \\
\hline 63 staff \\
\hline
\end{tabular}

\begin{tabular}{|c|}
\hline$\%$ \\
\hline $15.9 \%$ \\
\hline $84.1 \%$ \\
\hline $100 \%$ \\
\hline
\end{tabular}

Based on Table 4, it iwas known that from 63 medical record personnel who had participated on medical records training, there were only ten people $(15.9 \%)$ and who had never participated on medical record training were 53 people (84.1\%).

TABLE 5: The Distribution of Medical Record Personnel Based on Length of Service Period, the Year 2016.

\begin{tabular}{|l|c|c|c|c|}
\hline Average & Median & Stand. Deviation & Min-Max & $95 \% \mathbf{C l}$ \\
\hline 10.13 Years & 10 Years & 5.90 Years & $1-23$ Years & $8.64-11.61$ \\
\hline
\end{tabular}

Based on Table 5, generally, the length of the service period of medical records personnel in Community health center Serang was 10-year. Minimum length of service period from medical records staff was one year and the maximum length of service period of medical records personnel in Community health center Serang was 23 years old.

\section{Conclusions}

From the results of the research about Analysis of Medical Record Personnel Distribution on Medical Record and Health Information Services in Health Center in Serang City 2016, it could be concluded that:

1. The number of medical record personnel of 16 Community health center in Serang were 63 personnel. The number of medical records personnel at each Community health center had met regulatory standards PERMENKES No. 340/MenkesPer/III/ 2010, with average three personnel.

2. The number of medical records personnel who had medical records and health information education background was 11 (17.4\%) and 52 (82.5\%) personnel had no education background of medical records and health information.

3. The number of medical records personnel with the status as a permanent employee were 48 (76.2\%), and medical records personnel with contracted employee status were 15 (23.8\%). 
4. The personnel who had a history of medical records training were 10 (15.9\%) and 53 (84.1\%) medical records personnel had never participated in the practice of medical records.

5. In average personnel medical records in Community health center Serang had a length of ten years service period. The shortest of the service period was one year, and the longest was 23 years.

\section{Suggestions}

From the results of the research about Analysis of Medical Record Personnel Distribution on Medical Record and Health Information Services in Health Center in Serang City 2016, the researchers gave some advice for the benefit of Community health center and other interested parties, namely:

1. It is expected to recruit new medical records personnel in Community health center in Serang who has medical records and health information education background.

2. It expected to have a plan to establish medical records and health information unit for the processing of data and health information, especially following the requirements for accreditation of Community health center that requires medical records unit.

3. Each of Head of Community health center Serang should provide opportunities and facilities to medical records personnel for training on medical records held by the professional organization of medical history and health information.

4. It is expected Banten Province to give more allocation number for medical record personnel on their recruitment program in 2016.

\section{References}

[1] Departemen Kesehatan Republik Indonesia. 2004.Keputusan Menteri Kesehatan Republik Indonesia Nomor 128/Menkes/Sk/II/2004 Tentang Kebijakan Dasar Pusat Kesehatan Masyarakat Menteri Kesehatan Republik Indonesia.Depkes RI: Jakarta.

[2] Departemen KesehatanRepublik Indonesia. 2007. Keputusan Menteri Kesehatan Republik Indonesia No.377/MENKES/SK/III/2007 tentang Standar Profesi Perekam Medis dan Informasi Kesehatan. Depkes RI: Jakarta. 
[3] Departemen Kesehatan Republik Indonesia. 2008. Peraturan Menteri Kesehatan Republik Indonesia No.269/MENKES/2008 Tentang Rekam Medis. Depkes RI: Jakarta.

[4] Kementerian Kesehatan Republik Indonesia. 2010. Peraturan Menteri Kesehatan Republik Indonesia No.340/MENKES/SK/III/2010 tentang Klasifikasi Rumah Sakit. Kemenkes RI: Jakarta. 